\title{
Juvenile overlap myositis
}

INSERM

\section{Source}

INSERM. (1999). Orphanet: an online rare disease and orphan drug data base. Juvenile overlap myositis. ORPHA:329894

Juvenile overlap myositis is a rare juvenile idiopathic inflammatory myopathy characterized by the association of inflammatory myositis (manifesting with acral erythema, progressive weakness of the limbs, pain, general fatigue, moodiness or crankiness) with clinical and/or laboratory features of other autoimmune diseases (e.g. systemic lupus erythematosus, localized scleroderma, diabetes). Cardiac involvement has been reported in some patients. 